\title{
Alterations in growth and canopy architecture among dwarf, semidwarf and tall oat lines grown under northern conditions
}

\author{
Pirjo Mäkelä \\ Department of Applied Biology, Crop Production, PO Box 27, FIN-00014 University of Helsinki, Finland, \\ e-mail: pirjo.makela@helsinki.fi \\ Susanna Muurinen \\ Department of Applied Biology, Crop Production, PO Box 27, FIN-00014 University of Helsinki, Finland, \\ present address: MTT Agrifood Research Finland, Plant Production Research, 31600 Jokioinen, Finland
}

Pirjo Peltonen-Sainio

MTT Agrifood Research Finland, Plant Production Research, FIN-31600 Jokioinen, Finland

The Finnish growing season is particularly short, with an intensive growth period, unfavourable rainfall distribution and frequently occurring fluctuations in climate that affect crop growth and yield formation. A three-year study was conducted in the field to determine the contribution of alterations in canopy structure, tillering and stem elongation among dwarf (D), semidwarf (SD) and tall (T) oat (Avena sativa L.) lines to yield formation. Yield components, leaf characteristics and straw traits were measured from six oat lines (D lines Pal and Grane, SD lines Hja 76416 and Salo, and T lines Veli and Jalostettu maatiainen) separately on the main shoot and tillers. Results indicated that long leaf area duration and high leaf area index were associated with increased grain yield probably due to more persistent and active assimilation. Also, higher number of leaves increased the grain yield. Higher peduncle, straw and node weights associating with increased grain yield may result from more abundant assimilate reserves; however, the longer the straw and peduncle, the lower the grain yield, which may result from increased lodging of SD and T lines. The traits contributing most to the grain yield varied greatly from year to year. It is concluded that no single dominant trait determined grain yield, since yield is a product of several different traits. SD lines seemed to be most promising for further breeding programs on the basis of their growth pattern and yielding ability.

Key words: Avena sativa L., dwarfing gene, internode, leaf area, leaf area duration, plant height, plant stand 
Vol. 13 (2004): 170-185.

\section{Introduction}

Dwarfing genes have been effective sources for lodging control that have enabled higher input use and catalysed the Green Revolution. Brown et al. (1980) demonstrated with oat and Anderson and Smith (1990) and Grant et al. (1991) with wheat (Triticum aestivum L.) that lines differing in height due to introduction of dwarfing genes differed also in their response to growing conditions and crop management. Dwarf (D) and semidwarf (SD) wheat lines containing Rht 1 or Rht 2 alleles, often out-yielded their taller counterparts (Borrell et al. 1991, Donaldson et al. 2001). This is due to the dwarfing gene enhancing floret and grain set and survival (Anderson and Smith 1990, Borrell et al. 1991, Miralles and Slafer 1995). This may be associated with increased tillering of dwarf lines (Borrell et al. 1991). Youssefian et al. (1992) also demonstrated that stems competed less for nutrients, leading to a greater proportion of dry matter being partitioned to the ears of the Rht genotype. This occurs beginning with very early development stages and provides an avenue for production of a greater number of competent florets per ear, which favours grainset of dwarf lines (Youssefian et al. 1992). Higher grain number of SD and D lines in wheat contributes, however, to decreased grain weight (Flintham and Gale 1983, Pinthus and Levy 1983, Keyes and Sorrells 1989, Miralles and Slafer 1995), but this is not due to increased competition for assimilates. Rather, lines with dwarfing genes had a greater proportion of their grains at distal positions compared with $\mathrm{T}$ lines, and lower mean grain weight was a result of restricted assimilate transport capacity rather than source limitation (Miralles and Slafer 1995).

The primary effects of the dwarfing genes on growth are particularly well demonstrated for wheat, while few publications concern oat, and even fewer address the effect of the dwarfing gene $D w 6$ on growth of oat at high latitudes (Mäkelä et al. 1996). As lines carrying the dwarfing gene may express a photoperiod response, being thereby daylength sensitive like wheat
(Knott 1986), the development, growth and yield components of D and SD oat lines, compared with those of conventional height lines, may differ markedly when grown under northern growing conditions. Hence, this three-year study aimed to describe pre- and post-anthesis growth of D and SD oat lines at high latitudes and evaluate their yielding capacity and contribution to differences in tillering, leaf characteristics and source to sink interaction in productivity.

\section{Material and methods}

\section{Plant material and experimental design}

Field experiments were conducted in 1999, 2000 and 2001 at the Suitia Experimental Farm of the University of Helsinki $\left(60^{\circ} \mathrm{N}\right)$. Plant material consisted of six oat lines: Grane (D; $73 \mathrm{~cm}), \mathrm{Pal}$ (D; $70 \mathrm{~cm}$ ), Hja 76416 (SD; $81 \mathrm{~cm}$ ), Salo (SD; $80 \mathrm{~cm})$, Veli $(\mathrm{T} ; 104 \mathrm{~cm})$, and Jalostettu maatiainen $(\mathrm{T} ; 110 \mathrm{~cm})$.

Plots were sown on 18 May 1999, 10 May 2000 and 9 May 2001. Sowing density was 500 grains per square meter. Plots were fertilised with 80 kg N ha-1 (Pellon Y3, N-P-K:20-3-9, Kemira GrowHow, Finland). Weeds were controlled with Express 75DF (tribenuron methylene $750 \mathrm{~g} \mathrm{~kg}^{-1}$, suppl. Kemira GrowHow, Finland) annually at the four-leaf stage. The experiments were conducted in a randomised complete block design with five replications. Plot size was 10 square meters $(8 \mathrm{~m} \times 1.25 \mathrm{~m})$.

\section{Sampling and growth parameters}

Plant samples were collected every other week. Sampling began at the four-leaf stage. Ten random plants per plot were cut at ground level and used for analysis of leaf area formation and biomass accumulation. Each sample was divided into main shoot and tillers. Main shoots were measured for length $(\mathrm{cm})$ and further divided into 


\section{AGRICULTURAL AND FOOD SCIENCE}

\section{Mäkelä, P. et al. Growth and canopy architecture of oat}

head, leaf laminae, dead leaves (> 50\% of the area senescent), leaf sheaths, peduncle, nodes and the remainder of the stem. Number of tillers was recorded, and tillers were divided into fractions similar to the main shoots. All samples were dried and weighed $(\mathrm{g})$. Number of plants and heads per square meter, date of heading and maturity, and percentage of plot area lodged (\%) were recorded. Several additional parameters (Table 1) were calculated.

\section{Statistics}

Statistical analyses were carried out with the Statistical Analysis System (Littell et al. 1996).
LSMEANS and differences among LSMEANS were estimated using PROC MIXED. Forward elimination of stepwise regression analysis was used to determine the primary traits, which together made the greatest contribution to grain yield, harvest index (HI, \%), number of grains per plant, and plant total phytomass separately in different years.

Averaged over years Pal had lower grain yield than all other lines, and Pal and Salo had fewer

Table 1. Morpho-physiological traits measured and calculated for oat lines monitored in a field experiment carried out at Suitia Experimental Farm, Siuntio in Finland in 1999-2001.

\begin{tabular}{|c|c|}
\hline Trait & Definition, procedure, or formula \\
\hline 1. Grain yield, g plant ${ }^{-1}$ & Whole plant, tillers \\
\hline 2. Number of grains plant ${ }^{-1}$ & Whole plant, tillers \\
\hline 3. Phytomass, g plant $^{-1}$ & Weight of vegetative parts of the plant \\
\hline 4. Harvest index & $100 \times(1) /[(3) \times(1)]$ \\
\hline 3. Tillers, no. main shoot ${ }^{-1}$ & At maturity \\
\hline 5. Number of leaves plant ${ }^{-1}$ & At maturity \\
\hline 6. Weight of leaf laminae, g plant ${ }^{-1}$ & At maturity, main shoot \\
\hline 7. Weight of leaf sheaths, $g$ plant ${ }^{-1}$ & At maturity, main shoot \\
\hline 8. Leaf area index, $\mathrm{cm}^{2} \mathrm{~m}^{-2}$ & $\begin{array}{l}\text { Area of green leaf laminae } \mathrm{cm}^{2} \mathrm{~m}^{-2} \text { ground area; main shoot, tillers, and } \\
\text { the whole plant }\end{array}$ \\
\hline 9. Leaf area duration & $\begin{array}{l}f \mathrm{LAI} / \mathrm{dt} \text {, where } \mathrm{t} \text { is cumulated degree days }\left(\mathrm{dd}^{\circ} \mathrm{C} \text {, base temperature } 5^{\circ} \mathrm{C}\right) \\
\text { from seedling emergence to yellow ripeness; at pre-, post-, and anthesis }\end{array}$ \\
\hline 10. Specific leaf area, $\mathrm{m}^{2} \mathrm{~kg}^{-1}$ & $\begin{array}{l}\text { Area of green leaf laminae } \mathrm{m}^{2} \mathrm{~kg}^{-1} \text { weight of green leaves; at pre-, post-, } \\
\text { and anthesis }\end{array}$ \\
\hline 11. Number of leaves of the main shoot & At pre-, post-, and anthesis \\
\hline 12. Number of dead leaves of the main shoot & At pre-, post, and anthesis \\
\hline 13. Plant height, $\mathrm{cm}$ & Distance from soil surface to head tips at maturity \\
\hline 14. Weight of nodes, $g$ plant ${ }^{-1}$ & Main shoot \\
\hline 15. Length of peduncle, $\mathrm{cm}$ & Main shoot \\
\hline 16. Weight of peduncle, $g$ plant ${ }^{-1}$ & Main shoot \\
\hline 17. Length of straw, $\mathrm{cm}$ & Main shoot \\
\hline 18. Weight of internodes, $g_{\text {plant }}{ }^{-1}$ & Main shoot \\
\hline 19. Weight of leaves, g plant $^{-1}$ & Main shoot, tillers \\
\hline 20. Weight of straw, g plant ${ }^{-1}$ & Main shoot, tillers \\
\hline 21. Weight of panicles, g plant ${ }^{-1}$ & Main shoot, tillers \\
\hline 22. Tiller contribution to leaf area, $\%$ & $\begin{array}{l}\text { (Area of green leaf area of tillers/area of green leaf area of the whole } \\
\text { plant }) \times 100 \text {; tillers }\end{array}$ \\
\hline 23. Tiller harvest index, $\%$ & As (4) \\
\hline
\end{tabular}


Vol. 13 (2004): 170-185.

Table 2. Grain yield, harvest index, number of grains and plant total phytomass of oat lines monitored in a field experiment carried out at Suitia Experimental Farm, Siuntio in Finland in 1999 - 2001.

\begin{tabular}{|c|c|c|c|c|c|c|c|}
\hline \multirow{3}{*}{ Trait } & & \multicolumn{4}{|c|}{ Line } & & \\
\hline & & \multicolumn{2}{|c|}{ Dwarf } & \multicolumn{2}{|c|}{ Semidwarf } & \multicolumn{2}{|c|}{ Tall } \\
\hline & & Grane & Pal & Hja76416 & Salo & Jama* & Veli \\
\hline \multicolumn{8}{|c|}{ Grain yield (g plant $\left.{ }^{-1}\right)$} \\
\hline & 1999 & $1.66 \mathrm{ab}$ & $0.93 \mathrm{a}$ & $1.40 \mathrm{ab}$ & $1.48 \mathrm{ab}$ & $1.68 \mathrm{~b}$ & $1.41 \mathrm{ab}$ \\
\hline & 2000 & $1.82 \mathrm{ab}$ & $1.42 \mathrm{a}$ & $1.90 \mathrm{ab}$ & $1.86 \mathrm{ab}$ & $1.92 \mathrm{ab}$ & $2.25 \mathrm{~b}$ \\
\hline & 2001 & $2.20 \mathrm{~b}$ & $1.43 \mathrm{a}$ & $2.11 \mathrm{ab}$ & $1.88 \mathrm{ab}$ & $2.40 \mathrm{~b}$ & $2.51 \mathrm{~b}$ \\
\hline & mean & $1.89 \mathrm{~b}$ & $1.26 \mathrm{a}$ & $1.80 \mathrm{~b}$ & $1.74 \mathrm{~b}$ & $2.00 \mathrm{~b}$ & $2.06 \mathrm{~b}$ \\
\hline \multicolumn{8}{|c|}{ Harvest index $(\%)$} \\
\hline & 1999 & $56.9 \mathrm{~b}$ & $50.5 \mathrm{ab}$ & $52.0 \mathrm{ab}$ & $54.2 \mathrm{ab}$ & $52.5 \mathrm{ab}$ & 45.3 a \\
\hline & 2000 & 48.6 a & $46.5 \mathrm{a}$ & $55.5 \mathrm{a}$ & 53.7 a & $49.7 \mathrm{a}$ & 53.2 a \\
\hline & 2001 & $52.4 \mathrm{ab}$ & $47.0 \mathrm{a}$ & $57.2 \mathrm{~b}$ & $53.0 \mathrm{ab}$ & $52.7 \mathrm{ab}$ & $54.4 \mathrm{ab}$ \\
\hline & mean & $52.7 \mathrm{~b}$ & $48.0 \mathrm{a}$ & $54.9 \mathrm{~b}$ & $53.6 \mathrm{~b}$ & $51.6 \mathrm{ab}$ & $51.0 \mathrm{ab}$ \\
\hline \multicolumn{8}{|c|}{ Number of grains plant ${ }^{-1}$} \\
\hline & 1999 & $49 \mathrm{ab}$ & $30 \mathrm{a}$ & $51 \mathrm{ab}$ & $39 \mathrm{ab}$ & $54 \mathrm{~b}$ & $51 \mathrm{ab}$ \\
\hline & 2000 & $61 \mathrm{ab}$ & $49 \mathrm{a}$ & $74 \mathrm{~b}$ & $53 \mathrm{ab}$ & $64 \mathrm{ab}$ & $69 \mathrm{ab}$ \\
\hline & 2001 & $73 \mathrm{ab}$ & $51 \mathrm{a}$ & $76 a b$ & 56 a & $77 \mathrm{ab}$ & $79 \mathrm{ab}$ \\
\hline & mean & $61 \mathrm{~b}$ & $43 \mathrm{a}$ & $67 \mathrm{~b}$ & $49 \mathrm{a}$ & $65 \mathrm{~b}$ & $66 \mathrm{~b}$ \\
\hline \multicolumn{8}{|c|}{ Plant phytomass (g plant ${ }^{-1}$ ) } \\
\hline & 1999 & $2.90 \mathrm{a}$ & $1.83 \mathrm{a}$ & $2.69 \mathrm{a}$ & $2.74 \mathrm{a}$ & $3.22 \mathrm{a}$ & $3.07 \mathrm{a}$ \\
\hline & 2000 & $4.09 \mathrm{a}$ & $3.06 \mathrm{a}$ & $3.41 \mathrm{a}$ & $3.45 \mathrm{a}$ & $3.87 \mathrm{a}$ & $4.22 \mathrm{a}$ \\
\hline & 2001 & $4.21 \mathrm{ab}$ & $3.04 \mathrm{a}$ & $3.68 \mathrm{a}$ & $3.51 \mathrm{a}$ & $4.56 \mathrm{a}$ & $4.62 \mathrm{a}$ \\
\hline & mean & $3.74 \mathrm{ab}$ & $2.64 \mathrm{a}$ & $3.26 \mathrm{ab}$ & $3.23 \mathrm{a}$ & $3.88 \mathrm{ab}$ & $3.97 \mathrm{~b}$ \\
\hline
\end{tabular}

\# Means within each row not followed by the same letter are significantly different at $\mathrm{P} \leq 0.05$.

* Jama = Jalostettu maatiainen

grains per plant than the other lines evaluated (Table 2). The HI of Pal averaged over years was lower than Grane, Hja 76416 and Salo and similar to Veli and Jalostettu maatiainen. Pal is a dwarf oat with the $D w 6$ gene adapted to north- ern American growing conditions, while Salo is a semidwarf oat bred for Fenno-Scandian conditions. Even though the weather conditions varied over years (Table 3), there were no significant differences attributable to years.

Table 3. Monthly mean temperatures and precipitation for growing seasons 1999-2001 and the long-term means from 1971-1990 at Suitia Experimental Farm, Siuntio, Finland.

\begin{tabular}{lrrrrrrrr}
\hline & \multicolumn{3}{c}{ Mean temperature $\left({ }^{\circ} \mathrm{C}\right)$} & \multicolumn{4}{c}{ Precipitation (mm) } \\
Month & 1999 & 2000 & 2001 & Long-term & 1999 & 2000 & 2001 & Long-term \\
\hline April & 5.5 & 6.4 & 8.0 & 3.1 & 70 & 69.2 & 53 & 37 \\
May & 7.9 & 10.6 & 9.5 & 9.7 & 17 & 24.8 & 26.6 & 31 \\
June & 17.9 & 14.2 & 14.2 & 15.0 & 29 & 35.6 & 26.6 & 41 \\
July & 18.6 & 16.6 & 19.9 & 17.0 & 9.4 & 12.4 & 16.4 & 60 \\
August & 14.9 & 14.9 & 16.0 & 15.7 & 9.6 & 6.8 & 8.4 & 74 \\
September & 12.3 & 8.7 & 11.9 & 11.1 & 3.8 & 4.2 & 2.6 & 73 \\
\hline
\end{tabular}




\section{AGRICULTURAL AND FOOD SCIENCE}

\section{Mäkelä, P. et al. Growth and canopy architecture of oat}

\section{Leaf dynamics}

Leaf area index (LAI) tended to be lowest for D line Pal both when measured from the main shoot only and from the whole plant (Fig. 1). The highest LAI was recorded for $\mathrm{T}$ line Veli both from the main shoot and the whole plant. Though some variation among lines was demonstrated for tiller LAI, in most cases the oat lines studied did not significantly differ from each other or the difference was not of any practical importance. Lowest LAI of tillers tended to be for T Veli. There were, however, differences over years in the highest LAI of tillers. The specific leaf area (SLA, $\mathrm{m}^{2} \mathrm{~kg}^{-1}$ ) was not significantly different among the lines studied when measured at pre- and post-anthesis (data not shown); however, when measurements were made at anthesis, some significant differences occurred: in 2001, SLA was lower in D Pal and D Grane than in T Jalostettu maatiainen and SD Salo. The oat lines did not differ significantly from each other in main shoot leaf area duration (LAD) with the only exception that D Pal was among the lowest in 2000 (Table 4). The number of leaves and dead leaves of lines studied varied slightly from year to year (Table 4). The final number of leaves and the weight of leaf laminae and sheath were lowest for D Pal when averaged over years (Table 5). Leaf laminae weighed the most in T Veli and sheath in $\mathrm{D}$ Grane, $\mathrm{T}$ Jalostettu maatiainen and $\mathrm{T}$ Veli when averaged over years.

Stepwise regression analysis indicated that leaf number in 1999 accounted for some $88 \%$ of the grain yield per plant (Table 6). In comparison, the heavier leaf sheaths and leaves were associated with lower grain yield, whereas persistent post-anthesis LAD appeared to increase the grain yield. In 2000, post-anthesis LAD alone contributed $83 \%$ of the grain yield. Further contribution was made by pre-anthesis SLA. Similarly to 1999 , heavier leaf sheaths were associated with lower grain yield. In 2001, higher preanthesis LAD seemed to result in higher grain yield, but as in 1999, the heavier the leaves the less the grain yield.
High pre-anthesis LAD correlated positively with the number of grains per plant in 1999 and 2001 (Table 6). In 1999, a further contribution of $3 \%$ was attributable to high post-anthesis SLA. In 2000, increase in pre-anthesis SLA was associated with higher number of grains, and a further contribution of $29 \%$ was obtained with post-anthesis number of leaves and an additional $12 \%$ with number of dead leaves. In 2001, the second and third highest traits were anthesis SLA and post-anthesis LAD, which both decreased the number of grains the higher their values.

In 1999, high pre-anthesis SLA did not result in higher HI, but the opposite (Table 6). HI was, however, higher the greater the number of dead leaves at post-anthesis in 1999 and 2000. In 2000 , the greatest contribution to HI was recorded for pre-anthesis leaf number. 2001 differed from both previous years as increase in LAI resulted in higher HI. However, both heavier leaf sheaths and larger number of leaves at the postanthesis stage decreased HI.

In 2000 and 2001, heavier leaf sheaths contributed $96 \%$ to phytomass of the whole plant (Table 6). In 1999, the highest contribution was obtained with leaf number (94\%). Further contributions of up to $100 \%$ were obtained with preanthesis SLA, post-anthesis number of leaves and pre-anthesis LAD in 1999, 2000, and 2001, respectively.

\section{Tiller dynamics}

There were no differences among the oat lines in pre-anthesis tiller LAD in 1999-2001. Only slight differences were recorded among the lines evaluated at the post-anthesis stage in 2001 (Table 4). Similarly, percentage of leaf area of tillers for whole plants were only slightly different among lines studied. Average over years, number of tillers was higher in D Pal than in D Grane, SD Hja 76416, T Jalostettu maatiainen and T Veli (Table 7). No differences among lines were found in total weight of tiller leaves and tiller straw per plant. 
Vol. 13 (2004): 170-185.
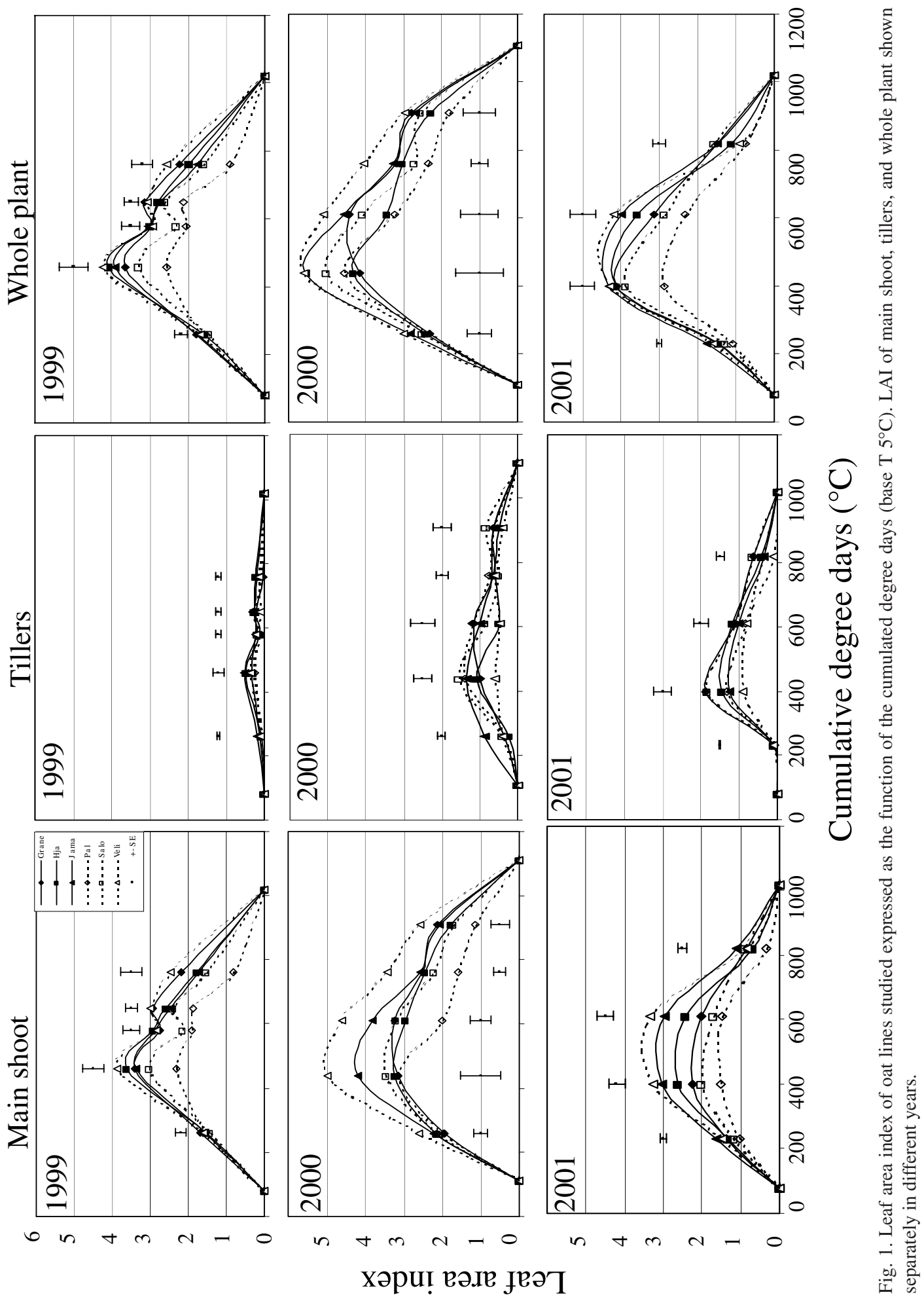
Mäkelä, P. et al. Growth and canopy architecture of oat

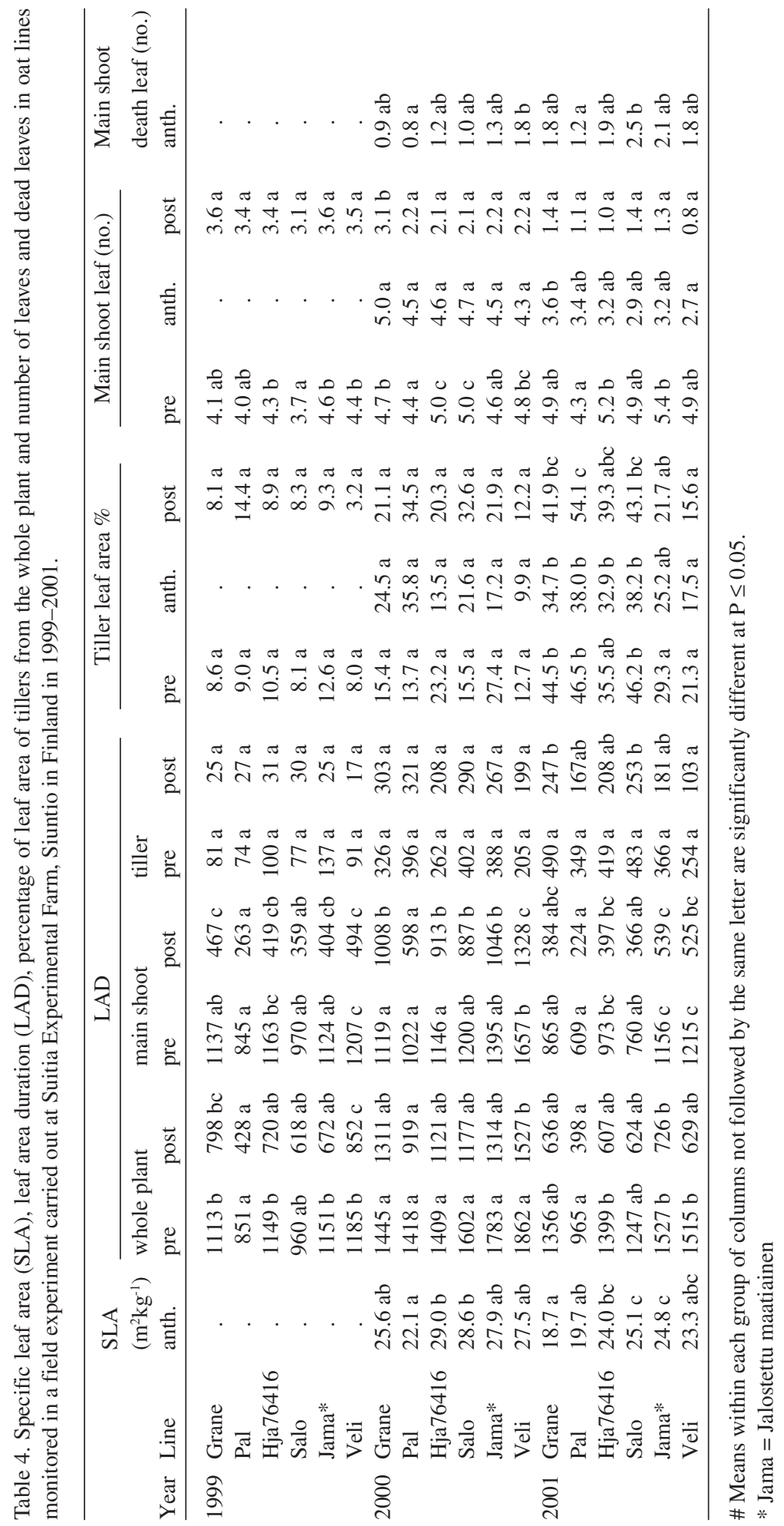


Vol. 13 (2004): 170-185.

Table 5. Primary traits of leaf dynamics of different oat cultivars on years 1999-2001.

\begin{tabular}{|c|c|c|c|c|c|c|c|}
\hline \multirow[t]{3}{*}{ Leaf Traits } & & \multicolumn{4}{|c|}{ Line } & & \\
\hline & & \multicolumn{2}{|c|}{ Semidwarf } & \multicolumn{2}{|c|}{ Dwarf } & \multicolumn{2}{|c|}{ Tall } \\
\hline & & Grane & Pal & Hja76416 & Salo & Jama* & Veli \\
\hline \multicolumn{8}{|c|}{ Leaf Number (no.) } \\
\hline & 1999 & $4.5 \mathrm{a}$ & $3.7 \mathrm{a}$ & $4.1 \mathrm{a}$ & $4.3 \mathrm{a}$ & $4.7 \mathrm{a}$ & $4.5 \mathrm{a}$ \\
\hline & 2000 & $3.4 \mathrm{a}$ & $3.2 \mathrm{a}$ & $3.5 \mathrm{a}$ & $3.6 \mathrm{a}$ & $3.6 \mathrm{a}$ & $3.4 \mathrm{a}$ \\
\hline & 2001 & $3.8 \mathrm{a}$ & $3.2 \mathrm{a}$ & $4.0 \mathrm{a}$ & $3.7 \mathrm{a}$ & $4.2 \mathrm{a}$ & $4.2 \mathrm{a}$ \\
\hline & mean & $3.9 \mathrm{~b}$ & $3.4 \mathrm{a}$ & $3.8 \mathrm{~b}$ & $3.9 \mathrm{~b}$ & $4.2 \mathrm{~b}$ & $4.0 \mathrm{~b}$ \\
\hline \multicolumn{8}{|c|}{ Lamina $\left(\right.$ g plant $\left.^{-1}\right)$} \\
\hline & 1999 & $0.193 \mathrm{a}$ & $0.090 \mathrm{a}$ & $0.152 \mathrm{a}$ & $0.140 \mathrm{a}$ & $0.179 \mathrm{a}$ & $0.23 \mathrm{a}$ \\
\hline & 2000 & $0.185 \mathrm{a}$ & $0.108 \mathrm{a}$ & $0.145 \mathrm{a}$ & $0.160 \mathrm{a}$ & $0.158 \mathrm{a}$ & $0.201 \mathrm{a}$ \\
\hline & 2001 & $0.171 \mathrm{a}$ & $0.094 \mathrm{a}$ & $0.137 \mathrm{a}$ & $0.136 \mathrm{a}$ & $0.179 \mathrm{a}$ & $0.219 \mathrm{a}$ \\
\hline & mean & $0.183 \mathrm{c}$ & $0.097 \mathrm{a}$ & $0.145 \mathrm{~b}$ & $0.145 \mathrm{~b}$ & $0.172 \mathrm{c}$ & $0.218 \mathrm{~d}$ \\
\hline \multicolumn{8}{|c|}{ Sheath $\left(\mathrm{g} \mathrm{plant}^{-1}\right)$} \\
\hline & 1999 & $0.250 \mathrm{a}$ & $0.154 \mathrm{a}$ & $0.221 \mathrm{a}$ & $0.206 \mathrm{a}$ & $0.265 \mathrm{a}$ & $0.293 \mathrm{a}$ \\
\hline & 2000 & $0.299 \mathrm{a}$ & $0.224 \mathrm{a}$ & $0.255 \mathrm{a}$ & $0.256 \mathrm{a}$ & $0.305 \mathrm{a}$ & $0.324 \mathrm{a}$ \\
\hline & 2001 & $0.284 \mathrm{a}$ & $0.191 \mathrm{a}$ & $0.214 \mathrm{a}$ & $0.219 \mathrm{a}$ & $0.310 \mathrm{a}$ & $0.327 \mathrm{a}$ \\
\hline & mean & $0.278 \mathrm{c}$ & $0.189 \mathrm{a}$ & $0.230 \mathrm{~b}$ & $0.227 \mathrm{~b}$ & $0.293 \mathrm{~cd}$ & $0.315 \mathrm{~d}$ \\
\hline
\end{tabular}

\# Means within each row not followed by the same letter are significantly different at $\mathrm{P} \leq 0.05$.

* Jama = Jalostettu maatiainen

Table 6. Contribution of primary traits of leaf dynamics after the forward elimination of stepwise regression analysis to the grain yield, harvest index, number of grains per plant, and plant phytomass on years 1999-2001.

\begin{tabular}{|c|c|c|c|c|c|c|c|c|c|c|c|c|}
\hline \multicolumn{5}{|l|}{ Dependent Variable } & \multicolumn{8}{|c|}{ Independent traits } \\
\hline & Intercept & \multicolumn{2}{|l|}{ First } & \multirow[t]{2}{*}{$\mathrm{R}^{2}$} & \multicolumn{2}{|l|}{ Second } & \multirow[t]{2}{*}{$\mathrm{R}^{2}$} & \multicolumn{2}{|l|}{ Third } & \multirow[t]{2}{*}{$\mathrm{R}^{2}$} & Fourth & \multirow[t]{2}{*}{$\mathrm{R}^{2}$} \\
\hline \multicolumn{9}{|l|}{ Grain yield (g plant $\left.{ }^{-1}\right)$} & & & & \\
\hline 1999 & -2.75 & leaf numb. & 0.981 & 0.88 & leaf $\mathrm{tg}$ & -1.06 & 0.92 & LADpost & 0.002 & 0.98 & -5.843 & 1.00 \\
\hline 2000 & -1.22 & LADpost & 0.002 & 0.83 & SLApre & 0.07 & 0.98 & leaf $\mathrm{tg}$ & -3.87 & 1.00 & & \\
\hline 2001 & -0.06 & LADpre & 0.001 & 0.96 & leaf $g$ & 3.41 & 1.00 & & & & & \\
\hline \multicolumn{13}{|l|}{ Harvest index (\%) } \\
\hline 1999 & 146.00 & SLApre & -4.82 & 0.27 & DLNpost & 15.72 & 0.75 & & & & & \\
\hline 2000 & -22.04 & LNpre & 14.05 & 0.88 & DLNpost & 3.16 & 0.99 & & & & & \\
\hline 2001 & 36.51 & LAI & 8.57 & 0.67 & leaf $\mathrm{tg}$ & -46.84 & 0.89 & LNpost & -4.53 & 1.00 & & \\
\hline \multicolumn{13}{|l|}{ Number of grains plant ${ }^{-1}$} \\
\hline 1999 & -49.62 & LADpre & 0.068 & 0.95 & SLApost & 1.04 & 0.98 & & & & & \\
\hline 2000 & -217.34 & SLApre & 7.413 & 0.58 & LNpost & 20.56 & 0.87 & DLNpost & 11.2 & 0.99 & & \\
\hline 2001 & 6.98 & LADpre & 0.114 & 0.86 & SLAanth & -1.55 & 0.94 & LADpost & -0.06 & 0.97 & leaf $g-111.7$ & 1.00 \\
\hline \multicolumn{13}{|l|}{ Plant phytomass } \\
\hline 1999 & -5.19 & leaf numb. & 1.033 & 0.94 & SLApre & 0.12 & 0.99 & & & & & \\
\hline 2000 & 0.19 & leaf $\mathrm{tg}$ & 10.83 & 0.96 & LNpost & 0.21 & 0.99 & & & & & \\
\hline 2001 & 0.55 & leaf $\mathrm{tg}$ & 7.675 & 0.96 & LADpre & 0.00 & 1.00 & & & & & \\
\hline
\end{tabular}

leaf numb. $=$ Number of leaves of the main shoot at maturity

LAD pre/post $=$ Leaf area duration at pre- or postanthesis (whole plant)

SLA pre/anth/post $=$ Specific leaf area at pre-, post- and anthesis

LN pre/post $=$ Number of leaves of the main shoot at pre- and postanthesis

DLN post $=$ Number of dead leaves of the main shoot at the pre- and post anthesis

leaf $\mathrm{g}=$ weight of main shoot leaf laminae at maturity

leaf $\mathrm{t} g=$ weight of the main shoot leaf sheats

$\mathrm{LAI}=$ maximum leaf area index of the whole plant 
Mäkelä, P. et al. Growth and canopy architecture of oat

Table 7. Primary traits of tiller dynamics of different oat lines on years 1999-2001.

\begin{tabular}{|c|c|c|c|c|c|c|c|}
\hline \multirow[t]{3}{*}{ Tiller Traits } & & \multicolumn{4}{|c|}{ Line } & & \\
\hline & & \multicolumn{2}{|c|}{ Dwarf } & \multicolumn{2}{|c|}{ Semidwarf } & \multicolumn{2}{|c|}{ Tall } \\
\hline & & Grane & Pal & Hja76416 & Salo & Jama* & Veli \\
\hline \multicolumn{8}{|c|}{ Leaf $\left(g_{\text {plant }}{ }^{-1}\right)$} \\
\hline & 1999 & $0.009 \mathrm{a}$ & $0.020 \mathrm{a}$ & $0.011 \mathrm{a}$ & $0.014 \mathrm{a}$ & $0.023 \mathrm{a}$ & $0.021 \mathrm{a}$ \\
\hline & 2000 & $0.050 \mathrm{a}$ & $0.071 \mathrm{a}$ & $0.036 \mathrm{a}$ & $0.039 \mathrm{a}$ & $0.039 \mathrm{a}$ & $0.027 \mathrm{a}$ \\
\hline & 2001 & $0.128 \mathrm{a}$ & $0.073 \mathrm{a}$ & $0.087 \mathrm{a}$ & $0.113 \mathrm{a}$ & $0.104 \mathrm{a}$ & $0.085 \mathrm{a}$ \\
\hline & mean & $0.062 \mathrm{a}$ & $0.055 \mathrm{a}$ & $0.045 \mathrm{a}$ & $0.055 \mathrm{a}$ & $0.056 \mathrm{a}$ & $0.044 \mathrm{a}$ \\
\hline \multicolumn{8}{|c|}{ Straw $\left(\right.$ g plant $\left.^{-1}\right)$} \\
\hline & 1999 & $0.034 \mathrm{a}$ & $0.183 \mathrm{a}$ & $0.173 \mathrm{a}$ & $0.091 \mathrm{a}$ & $0.111 \mathrm{a}$ & $0.064 \mathrm{a}$ \\
\hline & 2000 & $0.864 \mathrm{a}$ & $0.460 \mathrm{a}$ & $0.188 \mathrm{a}$ & $0.226 \mathrm{a}$ & $0.240 \mathrm{a}$ & $0.090 \mathrm{a}$ \\
\hline & 2001 & $0.560 \mathrm{a}$ & $0.565 \mathrm{a}$ & $0.357 \mathrm{a}$ & $0.408 \mathrm{a}$ & $0.448 \mathrm{a}$ & $0.343 \mathrm{a}$ \\
\hline & mean & $0.486 \mathrm{a}$ & $0.403 \mathrm{a}$ & $0.239 \mathrm{a}$ & $0.242 \mathrm{a}$ & $0.266 \mathrm{a}$ & $0.165 \mathrm{a}$ \\
\hline \multicolumn{8}{|c|}{ Panicle $\left(\mathrm{g}_{\text {plant }}{ }^{-1}\right)$} \\
\hline & 1999 & $0.107 \mathrm{a}$ & $0.182 \mathrm{a}$ & $0.039 \mathrm{a}$ & $0.107 \mathrm{a}$ & $0.139 \mathrm{a}$ & $0.056 \mathrm{a}$ \\
\hline & 2000 & $0.306 \mathrm{a}$ & $0.448 \mathrm{a}$ & $0.241 \mathrm{a}$ & $0.274 \mathrm{a}$ & $0.194 \mathrm{a}$ & $0.050 \mathrm{a}$ \\
\hline & 2001 & $0.852 \mathrm{a}$ & $0.604 \mathrm{a}$ & $0.568 \mathrm{a}$ & $0.727 \mathrm{a}$ & $0.516 \mathrm{a}$ & $0.404 \mathrm{a}$ \\
\hline & mean & $0.422 \mathrm{~b}$ & $0.411 \mathrm{~b}$ & $0.283 \mathrm{ab}$ & $0.369 \mathrm{ab}$ & $0.283 \mathrm{ab}$ & $0.170 \mathrm{a}$ \\
\hline \multicolumn{8}{|c|}{ Harvest index (\%) } \\
\hline & 1999 & $47.5 \mathrm{a}$ & $45.7 \mathrm{a}$ & $25.6 \mathrm{a}$ & $38.9 \mathrm{a}$ & $42.1 \mathrm{a}$ & $28.5 \mathrm{a}$ \\
\hline & 2000 & $38.2 \mathrm{a}$ & $38.2 \mathrm{a}$ & $42.8 \mathrm{a}$ & $37.1 \mathrm{a}$ & $19.9 \mathrm{a}$ & $21.3 \mathrm{a}$ \\
\hline & 2001 & $47.9 \mathrm{a}$ & $41.7 \mathrm{a}$ & $49.7 \mathrm{a}$ & $46.2 \mathrm{a}$ & $41.1 \mathrm{a}$ & $42.8 \mathrm{a}$ \\
\hline & mean & $44.5 \mathrm{~b}$ & $41.8 \mathrm{ab}$ & $39.4 \mathrm{ab}$ & $40.7 \mathrm{ab}$ & $34.4 \mathrm{ab}$ & $30.8 \mathrm{a}$ \\
\hline \multicolumn{8}{|c|}{ Tiller number main shoot ${ }^{-1}$} \\
\hline & 1999 & $0.4 \mathrm{a}$ & $0.8 \mathrm{a}$ & $0.5 \mathrm{a}$ & $0.6 \mathrm{a}$ & $0.8 \mathrm{a}$ & $0.5 \mathrm{a}$ \\
\hline & 2000 & $1.2 \mathrm{ab}$ & $2.3 \mathrm{~b}$ & $1.1 \mathrm{ab}$ & $1.2 \mathrm{ab}$ & $1.1 \mathrm{ab}$ & $0.7 \mathrm{a}$ \\
\hline & 2001 & $2.0 \mathrm{a}$ & $2.4 \mathrm{a}$ & $1.8 \mathrm{a}$ & $2.3 \mathrm{a}$ & $1.6 \mathrm{a}$ & $1.3 \mathrm{a}$ \\
\hline & mean & $1.2 \mathrm{a}$ & $1.8 \mathrm{~b}$ & $1.1 \mathrm{a}$ & $1.4 \mathrm{ab}$ & $1.1 \mathrm{a}$ & $0.8 \mathrm{a}$ \\
\hline
\end{tabular}

\# Means within each row not followed by the same letter are significantly different at $\mathrm{P} \leq 0.05$.

* Jama = Jalostettu maatiainen

According to the stepwise regression analysis, in 1999 grain yield per plant seemed to decrease with increase in tiller straw weight (Table 8). In 2000, it also seemed that the higher the tiller panicle weight and number of tillers, the lower the grain yield per plant. In 2001, number of tillers again contributed negatively to the grain yield, but tiller leaf weight seemed to contribute positively to grain yield.

Number of grains per plant was higher the higher the pre-anthesis LAD of the tillers in 1999 (Table 8). In 2000, number of grains per plant correlated negatively with post-anthesis LAD of tillers. Increased number of tillers was also as- sociated with less grains per plant both in 1999 and in 2001. Heavier straw of tillers and higher percentage of tiller leaf area of the whole plant seemed to be linked with more grains per plant.

Whole plant HI was mostly increased by postanthesis tiller LAD and decreased by straw weight of tillers (Table 8). High HI of tillers was associated with high $\mathrm{HI}$ of the whole plant in all years. Heavier leaves and straws of tillers was associated negatively with the HI of whole plants. In 2000, a further contribution (10\%) to $\mathrm{HI}$ of the whole plant was associated with the higher number of tillers. However, in 2001, it seemed that the increase in percentage leaf area 
Vol. 13 (2004): 170-185.

of tillers of the whole plant was associated negatively by about $11 \%$ with the HI of the whole plant.

In 1999-2001, the higher percentage of tiller leaf area of the whole plant was associated with lower whole plant phytomass (Table 8). In 1999, pre- and post-anthesis LAD increased the phytomass, whereas the heavier straw of the tillers seemed to decrease it. Similarly, in 2000, post-anthesis LAD of tillers contributed $18 \%$ to the increase in phytomass. Interestingly, in 2000, the heavier tiller panicles were attributable to decrease in phytomass, whereas in 2001 the opposite was recorded. In contrast to 1999, in 2001, the straw weight of tillers was positively associated with the phytomass, with a further contribution attributable to the HI of tillers.

\section{Straw dynamics}

Of the traits describing the straw, weight of nodes was highest in $\mathrm{T}$ line Veli when averaged over years (Table 9). The weight of internodes was highest in T Jalostettu maatiainen and T Veli and lowest in D Pal when averaged over years. Length of peduncle was highest in T Jalostettu maatiainen, intermediate in T Veli and SD Salo and lowest in D Grane, D Pal and SD Hja 76416. The weight of the peduncle was also highest in $\mathrm{T}$ Jalostettu maatiainen and Veli. As expected, the longest straw was in $\mathrm{T}$ lines Jalostettu maatiainen and Veli and the shortest in D lines Grane and Pal.

For the straw traits, the stepwise regression analysis revealed that grain yield was increased

Table 8. Contribution of primary traits of tiller dynamics after the forward elimination of stepwise regression analysis to the grain yield, harvest index, number of grains per plant, and plant phytomass on years 1999-2001.

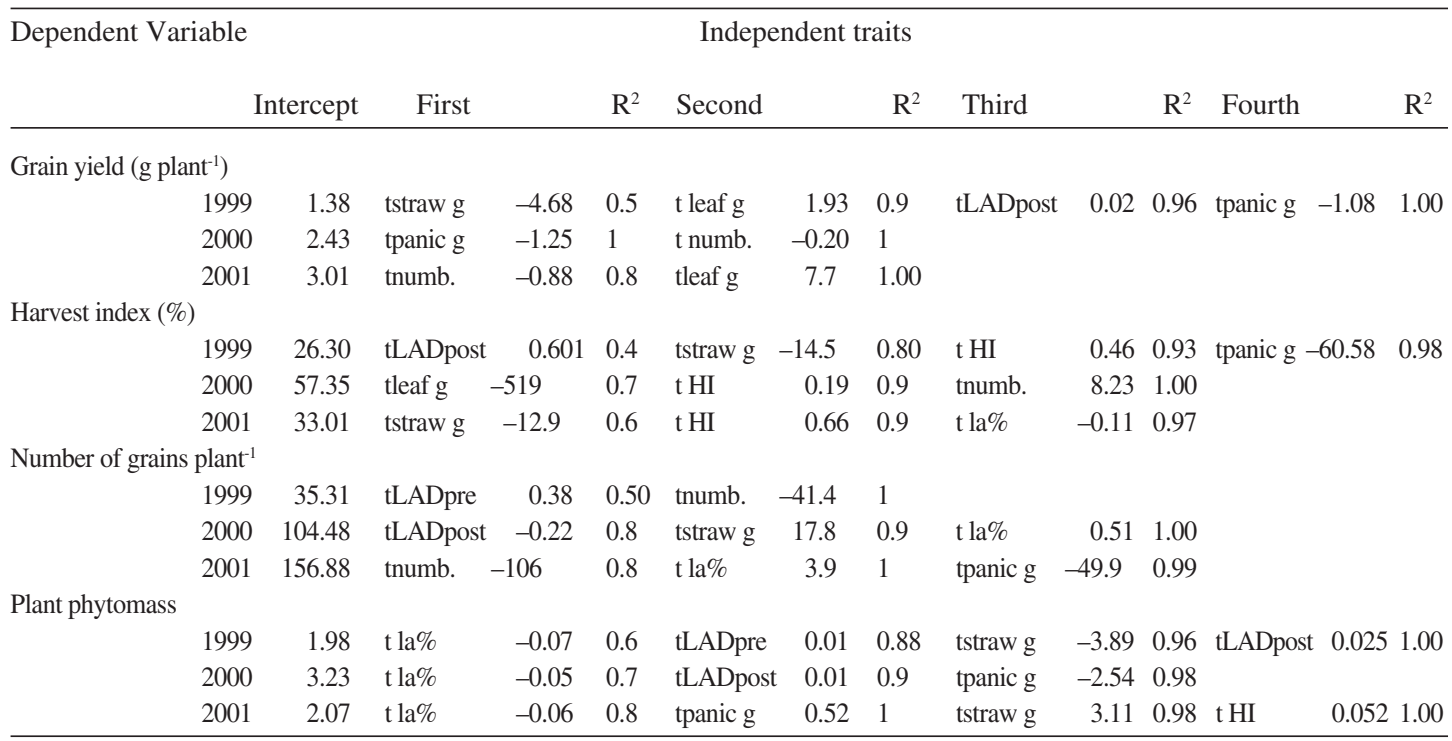

tstraw $g=$ Weight of tillers straw at maturity

tpanic $\mathrm{g}=$ Weight of tillers panicle at maturity

tleaf $\mathrm{g}=$ Weight of tillers leaves at maturity

tnumb. $=$ Number of tillers per plant

tLAD pre/post $=$ Leaf area duration of tillers at pre- or postanthesis

$\mathrm{t}$ la\% $=$ Tiller contribution to leaf area\%

$\mathrm{t} \mathrm{HI}=$ Harvest index of tillers 
Mäkelä, P. et al. Growth and canopy architecture of oat

Table 9. Primary traits of straw dynamics of different oat lines on years 1999-2001.

\begin{tabular}{|c|c|c|c|c|c|c|c|}
\hline \multirow[t]{3}{*}{ Straw Traits } & & \multicolumn{4}{|c|}{ Line } & & \\
\hline & & \multicolumn{2}{|c|}{ Dwarf } & \multicolumn{2}{|c|}{ Semidwarf } & \multicolumn{2}{|c|}{ Tall } \\
\hline & & Grane & Pal & Hja76416 & Salo & Jama* & Veli \\
\hline \multicolumn{8}{|c|}{ Node $\left(\right.$ g plant $\left.^{-1}\right)$} \\
\hline & 1999 & $0.070 \mathrm{a}$ & $0.048 \mathrm{a}$ & $0.065 \mathrm{a}$ & $0.062 \mathrm{a}$ & $0.093 \mathrm{a}$ & $0.105 \mathrm{a}$ \\
\hline & 2000 & $0.062 \mathrm{a}$ & $0.051 \mathrm{a}$ & $0.056 \mathrm{a}$ & $0.060 \mathrm{a}$ & $0.078 \mathrm{a}$ & $0.090 \mathrm{a}$ \\
\hline & 2001 & $0.073 \mathrm{a}$ & $0.052 \mathrm{a}$ & $0.060 \mathrm{a}$ & $0.056 \mathrm{a}$ & $0.085 \mathrm{a}$ & $0.098 \mathrm{a}$ \\
\hline & mean & $0.069 \mathrm{~b}$ & $0.050 \mathrm{a}$ & $0.060 \mathrm{ab}$ & $0.060 \mathrm{ab}$ & $0.085 \mathrm{c}$ & $0.098 \mathrm{~d}$ \\
\hline \multicolumn{8}{|c|}{ Peduncle (cm) } \\
\hline & 1999 & $26.6 \mathrm{a}$ & $26.3 \mathrm{a}$ & $26.9 \mathrm{a}$ & $32.5 \mathrm{~b}$ & $36.6 \mathrm{~b}$ & $32.4 \mathrm{~b}$ \\
\hline & 2000 & $31.5 \mathrm{a}$ & $33.6 \mathrm{a}$ & $35.9 \mathrm{ab}$ & $40.3 \mathrm{~b}$ & $53.2 \mathrm{c}$ & $44.9 \mathrm{~b}$ \\
\hline & 2001 & $30.1 \mathrm{a}$ & $32.1 \mathrm{ab}$ & $30.9 \mathrm{a}$ & $34.4 \mathrm{ab}$ & $46.9 \mathrm{c}$ & $36.9 \mathrm{~b}$ \\
\hline & mean & $29.4 \mathrm{a}$ & $30.7 \mathrm{a}$ & $31.2 \mathrm{a}$ & $35.7 \mathrm{~b}$ & $45.6 \mathrm{c}$ & $38.1 \mathrm{~b}$ \\
\hline \multicolumn{8}{|c|}{ Peduncle $\left(\right.$ g plant $\left.^{-1}\right)$} \\
\hline & 1999 & $0.180 \mathrm{a}$ & $0.123 \mathrm{a}$ & $0.194 \mathrm{a}$ & $0.210 \mathrm{a}$ & $0.275 \mathrm{a}$ & $0.221 \mathrm{a}$ \\
\hline & 2000 & $0.192 \mathrm{a}$ & $0.209 \mathrm{a}$ & $0.239 \mathrm{a}$ & $0.256 \mathrm{a}$ & $0.329 \mathrm{a}$ & $0.319 \mathrm{a}$ \\
\hline & 2001 & $0.188 \mathrm{a}$ & $0.168 \mathrm{a}$ & $0.183 \mathrm{a}$ & $0.184 \mathrm{a}$ & $0.307 \mathrm{a}$ & $0.259 \mathrm{a}$ \\
\hline & mean & $0.187 \mathrm{a}$ & $0.167 \mathrm{a}$ & $0.205 \mathrm{ab}$ & $0.216 b$ & $0.304 \mathrm{c}$ & $0.267 \mathrm{c}$ \\
\hline \multicolumn{8}{|c|}{ Total Straw (cm) } \\
\hline & 1999 & $54.8 \mathrm{a}$ & $53.5 \mathrm{a}$ & $58.1 \mathrm{a}$ & $59.2 \mathrm{a}$ & $79.6 \mathrm{~b}$ & $73.9 \mathrm{~b}$ \\
\hline & 2000 & $63.0 \mathrm{a}$ & $64.0 \mathrm{a}$ & $70.7 \mathrm{ab}$ & $75.7 \mathrm{~b}$ & $105.2 \mathrm{~d}$ & $94.0 \mathrm{c}$ \\
\hline & 2001 & $54.0 \mathrm{a}$ & $55.2 \mathrm{a}$ & $58.0 \mathrm{a}$ & $60.9 \mathrm{a}$ & $82.8 \mathrm{c}$ & $69.7 \mathrm{~b}$ \\
\hline & mean & $57.3 \mathrm{a}$ & $57.6 \mathrm{a}$ & $62.3 \mathrm{~b}$ & $65.3 \mathrm{~b}$ & $89.2 \mathrm{~d}$ & $79.2 \mathrm{c}$ \\
\hline \multicolumn{8}{|c|}{ Internodes $\left(\mathrm{g}_{\text {plant }}{ }^{-1}\right)$} \\
\hline & 1999 & $0.332 \mathrm{a}$ & $0.202 \mathrm{a}$ & $0.321 \mathrm{a}$ & $0.373 \mathrm{a}$ & $0.487 \mathrm{a}$ & $0.515 \mathrm{a}$ \\
\hline & 2000 & $0.366 \mathrm{a}$ & $0.305 \mathrm{a}$ & $0.370 \mathrm{a}$ & $0.373 \mathrm{a}$ & $0.569 \mathrm{a}$ & $0.648 \mathrm{a}$ \\
\hline & 2001 & $0.314 \mathrm{a}$ & $0.240 \mathrm{a}$ & $0.285 \mathrm{a}$ & $0.252 \mathrm{a}$ & $0.420 \mathrm{a}$ & $0.458 \mathrm{a}$ \\
\hline & mean & $0.334 \mathrm{~b}$ & $0.249 \mathrm{a}$ & $0.325 \mathrm{~b}$ & $0.333 \mathrm{~b}$ & $0.492 \mathrm{c}$ & $0.540 \mathrm{c}$ \\
\hline
\end{tabular}

\# Means within each row not followed by the same letter are significantly different at $\mathrm{P} \leq 0.05$.

* Jama = Jalostettu maatiainen

due to heavier nodes in all years, although in 1999 the contribution was only $10 \%$; being $70 \%$ and $79 \%$ in 2000 and 2001 respectively (Table $10)$. In 1999, highest contribution to grain yield was made by peduncle weight (62\%). However, longer straw seemed be associated with decrease in grain yield. Number of grains per plant seemed to depend mostly on peduncle weight in 1999. Traits of secondary importance were peduncle length, which was associated negatively with the number of grains and node weight, which was associated positively with the number of grains per plant. In 2000, straw weight contributed most to the number of grains per plant, even though the contribution was only $26 \%$. In 2001 , the most important trait was the weight of nodes. Independent traits for HI were found only in 1999. At that time, the first and third most important traits were the weight of nodes and the length of the straw, which were negatively attributable to the HI. The second most important trait was weight of peduncle, which was positively attributable to the HI. There seemed to be several similar traits that contributed most to phytomass in all years. In 1999, the heavier peduncle resulted in higher phytomass, with a longer peduncle 
Vol. 13 (2004): 170-185.

Table 10. Contribution of primary traits of straw dynamics after the foward elimination of stepwise regression analysis to the grain yield, harvest index, number of grains and plant phytomass on years 1999-2001.

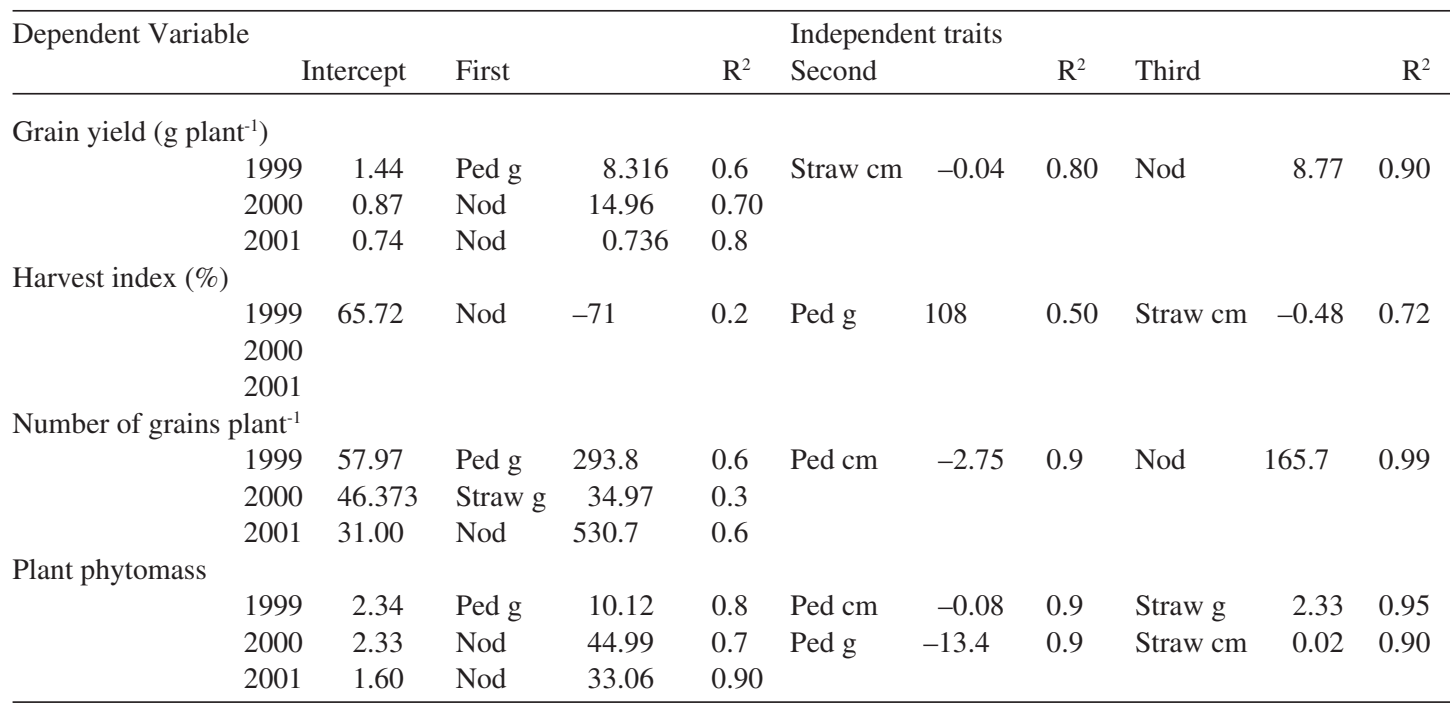

Ped $\mathrm{g}=$ Weight of main shoot peduncle at maturity Ped $\mathrm{cm}=$ Length of main shoot peduncle at maturity Nod = Weight of main shoot nodes at maturity Straw $g=$ Weight of main shoot internodes at maturity Straw $\mathrm{cm}=$ Length of main shoot straw at maturity

decreasing it and heavier straw increasing it again. In 2000 and 2001, weight of nodes was associated positively with the phytomass, whereas weight of peduncle was negatively associated and length of straw positively in 2000 .

\section{Discussion}

Dwarf lines did not seem to be able to use their earlier demonstrated tillering capacity (Simmons et al. 1982, Youssefian et al. 1992) for enhanced yield production in northern growing conditions. D line Pal together with SD line Salo had the highest tiller number per main shoot averaged over years. D line Pal was, however, systematically out-yielded by the other lines. This poor performance of D Pal is likely to be attributable to its poor adaptation to high latitudes and the Dw6 dwarfing gene.

In general, at least some of the tillers can be considered as early pre-anthesis assimilate reserves. Reserves are composites of assimilates produced 1) before anthesis and remobilised for grain filling, 2) after anthesis and translocated directly to the filling grains, and/or 3) after anthesis but stored temporarily in vegetative organs before remobilisation to the filling grains (Pheloung and Siddique 1991). Pre-anthesis assimilation was shown to contribute more than $44 \%$ of the grain dry matter under severe drought and $11 \%$ under wet conditions (Austin et al. 1980); however, according to El Alaoui et al. (1988), genotypes initiating relatively small numbers of tillers would be the best yielding. It is also possible that D lines have impaired enzymatic activity in assimilate translocation. According to Blum (1998), the enzymatic activity of assimi- 


\section{AGRICULTURAL AND FOOD SCIENCE}

\section{Mäkelä, P. et al. Growth and canopy architecture of oat}

late transport system is one of the most important factors affecting the ability of the plant to utilise reserve assimilates. The lighter internodes of D line Pal may have made them less able to store temporary assimilates when compared with D line Grane as well as T lines, especially since its stem weight density $\left(5.8 \mathrm{mg} \mathrm{cm}^{-1}\right)$ was the lowest of all lines. The other D line Grane had the second highest stem weight density $(7.1 \mathrm{mg}$ $\left.\mathrm{cm}^{-1}\right)$ after $\mathrm{T}$ line Veli $\left(8.1 \mathrm{mg} \mathrm{cm}^{-1}\right)$. That may indicate on the other hand that Grane has good stem reserves available if it also has the potential to utilise the reserves on grain filling. Moreover, Simmons et al. (1982) reported that high tillering lines tended to have smaller stem diameter, which made them also more susceptible to lodging. These factors may account for oat D line Pal being less able to fill grains efficiently, as indicated by the low grain to straw ratio in comparison to the SD lines. This was also recorded with different types of wheat even though they had equal number of florets and spikelets (Borrell et al. 1991). It seems that unlike with barley and wheat (Simmons et al. 1982, El Alaoui et al. 1988), with oat even yield producing tillers are not beneficial as they are associated with decreased grain yield of the whole plant at least when grown at high latitudes.

Results of this study are in accordance with Peltonen-Sainio (1997), in which tiller LAD in oat was shown not to contribute to grain yield or had a negative effect on it under northern growing conditions. When considering the whole plant, high LAD is among the traits making the most contribution to grain yield of oat (Peltonen-Sainio 1997) and wheat (Borojevic and Williams 1982). This can be partly explained by the possibility that oat might not be able to effectively translocate assimilates from the tiller leaves to the grains as from the main shoot reserves. Unlike with tillers, a higher number of leaves on the main shoot was associated in most cases with increased grain yield. This indicated possibly that there is an effective translocation system operating within the main shoot that favours grain filling.
In most cases, the D line Pal tended to be among the lines which had lowest pre- and postanthesis whole plant and main shoot LAD. Miralles and Slafer (1997) studied differences in radiation use efficiency (RUE) among $\mathrm{D}, \mathrm{SD}$ and $\mathrm{T}$ near-isogenic wheat lines and found $\mathrm{D}$ lines to operate very differently from the other lines. Dwarf lines had low pre-anthesis RUE associated with low biomass, while the highest post-anthesis RUE was possibly mediated by high sink capacity as a result of large number of grains per spike and grains per square meter (Miralles and Slafer 1997). Our results also indicated limitations in the translocation pathway of assimilates from tillers to the main shoot in D lines based on the number of tillers and grain yield, though they may even have higher photosynthetic capacity than T lines (Kulsrestha and Tsunoda 1981). This may be due to the changes caused by dwarfing genes in the mesophyll surface of leaves (LeCain et al. 1989). In studies conducted by Gent (1995), the light interception of $\mathrm{T}$ lines was $20 \%$ greater than that of D lines during stem elongation and at the boot stage, which may indicate poor canopy architecture caused by shortening of internodes (Calderini et al. 1996). Similarly, in our study, the internodes of D lines tended to be markedly shorter than in other lines evaluated. Miralles and Slafer (1997) studied light interception at pre- and post-anthesis and noted that D lines have more persistent RUE at post-anthesis, which was attributed to high sink demand generated by high grain number.

In barley and wheat, dwarf lines grown at lower latitudes usually yield about the same as, or more than, taller lines (Borrell et al. 1991, Donaldson et al. 2001, Singh et al. 2001, Milach and Federezzi 2001). This is probably due to reduced sensitivity to lodging, higher HI, more spikes and more kernels (Singh et al. 2001). However, that does not seem to be the case with oat, at least when grown at high latitudes (Mäkelä et al. 1996). It has been stated that use of dwarfing genes in oat breeding programmes has been very limited since the genes are usually associated with decrease in yield (Milach and Federezzi 2001). Similarly, in our experiments, D line 
Vol. 13 (2004): 170-185.

Pal had the lowest grain yield, while the other D line bred in Norway (Grane) had average grain yield when compared with SD and T lines. This indicates that D line Grane is adapted to grow and yield at high latitudes. The number of grains per plant was higher in SD line $\mathrm{Hja}$ 76416, T lines Jalostettu maatiainen and Veli, and D line Grane than in D line Pal and SD line Salo. At the same time, single grain weight was highest in SD line Salo (36 mg) and lowest in the other SD line Hja 76416 (27 mg). There are several reasons which might at least partly explain the yield decreases, since regardless of the height of the lines, grain number and spike number per square meter and number of kernels per spike are the main determinants of yield (Spiertz and van de Haar 1978, Donaldson et al. 2001). However, several physiological and morphological features compensate for differences in yield components (Major et al. 1992).

Poor stand establishment is a typical problem occurring with the SD lines at lower latitudes (Allan 1980), which does not seem to occur with Dw6 genotypes when grown under northern growing conditions (data not shown). Moreover, one of the drawbacks with D lines of oat possessing the Dw6 gene has been shortening of the peduncle (Kolb and Marshall 1984) leading to incomplete exsertion of the panicle from the flag leaf sheath (Farnham et al. 1990a, b). That was not observed in our studies, in which D lines Grane and Pal, and SD line Hja 76416 had peduncles 5 to $15 \mathrm{~cm}$ shorter than the other lines. Also, the straw in D lines was much shorter than in the SD lines and markedly shorter than in $\mathrm{T}$ lines. Similarly to D lines, the shortening of SD lines is mostly due to shorter internodes (Brown et al. 1980). At post-anthesis we did not record differences in total number of leaves (data not shown), which supports the finding of shorter internodes at northern latitudes.

In conclusion, for further breeding, SD lines seemed to be most promising on the basis of their growth pattern and yielding ability. Also, Norwegian D line Grane grew and yielded moderately in high latitudes, even though it possesses the $D w 6$ dwarfing gene. Thus, it can be conclud- ed that Dw6 gene could be used when breeding for stability and lodging resistance, which are important features for northern growing conditions, provided the lines are well adapted.

Acknowledgements. This project was partly funded by the University of Helsinki. We would like to thank Markku Tykkyläinen, Juha Kärkkäinen, Pauli Tiitinen, Ari Lahti and Jaana Nissi for their valuable assistance.

\section{References}

Allan, R.E. 1980. Influence of semidwarfism and genetic background on stand establishment of wheat. Crop Science 20: 634-638.

Anderson, W.K. \& Smith, W.R. 1990. Yield advantage of two semi-dwarf compared with two tall wheats depends on sowing time. Australian Journal of Agricultural Research 41: 811-826.

Austin, R.B., Morgan, C.L., Ford, M.A. \& Blackwell, R.D. 1980. Contributions to grain yield from pre-anthesis assimilation in tall and dwarf barley phenotypes in two contrasting seasons. Annals of Botany 45: 309319.

Blum, A. 1998. Improving wheat grain filling under stress by stem reserve mobilisation. Euphytica 100: 77-83.

Borojevic, S. \& Williams, W.A. 1982. Genotype x environment interactions for leaf area parameters and yield components and their effects on wheat yields. Crop Science 22: 1020-1028.

Borrell, A.K., Incoll, L.D. \& Dalling, M.J. 1991. The influence of the $R h t_{1}$ and $R h t_{2}$ alleles on the growth of wheat stems and ears. Annals of Botany 67: 103110.

Brown, P.D., McKenzie, R.I.H \& Mikaelsen, K. 1980. Agronomic, genetic, and cytologic evaluation of a vigorous new semidwarf oat. Crop Science 20: 303-306.

Calderini, D.F., Miralles, D.J. \& Sadras, V.O. 1996. Appearance and growth of individual leaves as affected by semidwarfism in isogenic lines of wheat. Annals of Botany 77: 583-589.

Donaldson, E., Schillinger, W.F. \& Dofing, S.M. 2001. Straw production and grain yield relationship in winter wheat. Crop Science 41: 100-106.

El Alaoui, A.C, Simmons, S.R. \& Crookston K.R. 1988. Effects of tiller removal on spring barley. Crop Science 28: 305-307.

Farnham, M.W., Stuthman, D.D. \& Biesboer, D.D. 1990. Cellular expression of panicle exsertion and peduncle elongation in semidwarf oat. Crop Science 30: 323-328.

Farnham, M.W., Stuthman, D.D. \& Pomeranke, G.J. 1990. Inheritance of and selection for panicle exsertion in semidwarf oat. Crop Science 30: 328-334.

Flintham, J.E. \& Gale, M.D. 1983. The Tom thumb dwarf- 


\section{AGRICULTURAL AND FOOD SCIENCE}

\section{Mäkelä, P. et al. Growth and canopy architecture of oat}

ing gene Rht3 in wheat 2. effects on height, yield and grain quality. Theoretical and Applied Genetics 66: 249-256.

Gent, M.P.N. 1995. Canopy light interception, gas exchange, and biomass in reduced height isolines of winter wheat. Crop Science 35: 1636-1642.

Grant, C.A., Gauer, L.E., Gehl, D.T. \& Bailey, L.D. 1991. Yield response of semidwarf and conventional height barley cultivars to nitrogen fertilizer under varying moisture conditions. Canadian Journal of Plant Science 71: 361-371.

Keyes, G. \& Sorrells, M.E. 1989. Rht1 and Rht2 semidwarf genes effect on hybrid vigor and agronomic traits of wheat. Crop Science 29: 1442-1447.

Knott, D.R. 1986. Effect of genes for photoperiodism, semidwarfism, and awns on agronomic characters in a wheat cross. Crop Science 26: 1158-1162.

Kolb, F.L. \& Marshall, H.G. 1984. Peduncle elongation in dwarf and normal height oats. Crop Science 24: 699703.

Kulshrestha, V.P. \& Tsunoda, S. 1981. The role of 'Norin 10 ' dwarfing genes in photosynthetic and respiratory activity of wheat leaves. Theoretical and Applied Genetics 60: 81-84.

LeCain, D.R., Morgan, J.A. \& Zerbi, G. 1989. Leaf anatomy and gas exchange in nearly isogenic semidwarf and tall winter wheat. Crop Science 29: 1246-1251.

Littell, R.C., Milliken, G.A., Stroup, W.W. \& Wolfinger, R.D. 1996. SAS system for mixed models. Cary, NC: SAS Institute Inc. $633 \mathrm{p}$.

Major, D.J., Janzen, H.H., Sadasivaiah, R.S. \& Carefoot, J.M. 1992. Morphological characteristics of wheat associated with high productivity. Canadian Journal of Plant Science 72: 689-698.

Mäkelä, P., Väärälä, L. \& Peltonen-Sainio, P. 1996. Agronomic comparison of Minnesota-adapted dwarf oat with semi-dwarf, intermediate, and tall oat lines adapted to northern growing conditions. Canadian Journal of Plant Science 76: 727-734.
Milach, S.C.K \& Federizzi, L.C. 2001. Dwarfing genes in plant improvement. Advances in Agronomy 73: 3563.

Miralles, D.J. \& Slafer, G.A. 1995. Individual grain weight responses to genetic reduction in culm length in wheat as affected by source-sink manipulations. Field Crops Research 43: 55-66.

Miralles, D.J. \& Slafer, G.A. 1997. Radiation interception and radiation use efficiency of near-isogenic wheat lines with different height. Euphytica 97: 201-208.

Pheloung, P.C. \& Siddique, K.H.M. 1991. Contribution of stem dry matter to grain yield in wheat cultivars. Australian Journal of Plant Physiology 18: 53-64.

Peltonen-Sainio, P. 1994. Growth duration and aboveground dry-matter partitioning in oats. Agricultural Science in Finland 3: 195-198.

Peltonen-Sainio, P. 1997. Leaf area duration of oat at high latitudes. Journal of Agronomy and Crop Science 178: 149-155.

Pinthus, M.J. \& Levy, A.A. 1983. The relationship between the $R h t_{1}$ and $R h t_{2}$ dwarfing genes and grain weight in Triticum aestivum L. spring wheat. Theoretical and Applied Genetics 66: 153-157.

Simmons, S.R., Rasmusson, D.C. \& Wiersma, J.V. 1982. Tillering in barley: genotype, row spacing, and seeding rate effects. Crop Science 22: 801-805.

Singh, R.P., Huerta-Espino, J., Rajaram, S. \& Crossa, J. 2001. Grain yield and other traits of tall and dwarf isolines of modern bread and durum wheats. Euphytica 119: 241-244.

Spiertz, J.H.J. \& van de Haar, H. 1978. Differences in grain growth, crop photosynthesis and distribution of assimilates between a semi-dwarf and a standard cultivar of winter wheat. Netherlands Journal of Agricultural Science 26: 233-249.

Youssefian, S., Kirby, E.J.M. \& Gale, M.D. 1992. Pleiotropic effects of the GA-insensitive Rht dwarfing genes in wheat. 2. Effects on leaf, stem, ear and floret growth. Field Crops Research 28: 191-210. 


\title{
SELOSTUS
}

\section{Korkeudeltaan eri tyyppisten kauralinjojen kasvu ja sadontuotto pohjoisissa viljelyoloissa}

\author{
Pirjo Mäkelä, Susanna Muurinen ja Pirjo Peltonen-Sainio \\ Helsingin yliopisto ja MTT (Maa- ja elintarviketalouden tutkimuskeskus)
}

Kasvien kasvua ja sadontuottoa rajoittaa Suomessa lyhyt ja nopeatempoinen kasvukausi, jolle on tyypillistä vaihteleva säätila ja sateiden epäedullinen painottuminen syksyyn. Kolmevuotisessa peltokokeessa tutkittiin eroja kääpiö-, ja puolikääpiökaurojen sekä pitkäkortisten lajikkeiden kasvustorakenteessa, sivuversojen tuotossa ja korrenkasvussa sekä arvioitiin näiden merkitystä sadonmuodostukseen. Kuuden kauralinjan pääversoista ja sivuversoista mitattiin satokomponentit sekä lehdistörakennetta ja kortta kuvaavia ominaisuuksia. Saatujen tulosten perusteella kääpiöt versoivat enemmän, mutta niiden sadontuottokyky ei parantunut versontakyvyn myötä. Määritetyistä ominaisuuksista korkeaan satoon olivat yhteydessä pitkään yhteyttämiskykyisenä säilyvä kasvusto ja suuri lehtialaindeksi, mikä saattaa johtua pitempään jatkuvasta tehokkaasta yhteyttämisestä. Myös suuri lehtilukumäärä lisäsi satoa. Kääpiöillä oli yleensä hieman vähemmän lehtiä kuin pitkäkortisilla lajikkeilla ja erityisesti Pal-lajikkeella epätyydyttävä kasvustorakenne. Hyvä sadontuottokyky oli yhteydessä painavampaan ylimpään nivelväliin, korteen ja solmuihin, mikä saattaa johtua siitä, että niissä oli enemmän välivarastoituja yhdisteitä, joita voitiin hyödyntää jyväntäyttymiseen. Pitkä korsi ja ylin nivelväli näyttivät kuitenkin olevan yhteydessä alhaiseen satoon johtuen oletettavasti lakoutumisalttiuden lisääntymisestä. Askeltava regressioanalyysi osoitti kuitenkin, että vuosittaiset vaihtelut olivat huomattavia ominaisuuksissa, jotka selittivät sadossa ilmenneitä vaihteluita. Siksi yksittäisiä, kasvuoloista riippumattomia, sadontuottoa hallitsevia ominaisuuksia ei voitu luonnehtia. 